\title{
Properties of a Biosurfactant Produced by Bacillus pumilus Using Vinasse and Waste Frying Oil as Alternative Carbon Sources
}

\author{
Juliana Guerra de Oliveira* and Crispin Humberto Garcia-Cruz \\ Departamento de Engenharia e Tecnologia de Alimentos; Universidade Estadual Paulista "Júlio de Mesquita \\ Filho"; Rua Cristóvão Colombo, 2265; 15054-000; São José do Rio Preto - SP - Brasil
}

\begin{abstract}
Biosurfactants are chemical molecules produced by the microorganisms with potential for application in various industrial and environmental sectors. The production parameters and the physicochemical properties of a biosurfactant synthesized by Bacillus pumilus using different concentrations of vinasse and waste frying oil as alternative carbon sources were analyzed. The microorganism was able to grow and produce a biosurfactant using both the residues. The surface tension was reduced up to $45 \mathrm{mN} / \mathrm{m}$ and the maximum production of crude biosurfactant was 27.7 and $5.7 \mathrm{~g} / \mathrm{l}$ for vinasse and waste frying oil, respectively, in concentration of 5\%. The critical micelle concentration (CMC) results of 1.5 and $0.2 \mathrm{~g} / \mathrm{l}$ showed the efficiency of the biosurfactant produced on both the substrates. The results showed that the alternative substrates could be used for the production of an efficient biosurfactant by B. pumilus. These properties have potential for industrial and environmental applications.
\end{abstract}

Key words: Biosurfactants, vinasse, waste frying oil, Bacillus pumilus

\section{INTRODUCTION}

Biosurfactants are surface-active molecules produced by the microorganisms (Nitschke and Pastore 2006). They have a wide variety of applications in the pharmaceutical, cosmetic and food industries (Yin et al. 2009). A variety of compounds include such as glycolipids, lipopeptides, lipoproteins, phospholipids, fatty acids, neutral lipids, polysaccharide-protein complexes and peptides (Benincasa et al. 2002; Yin et al. 2009).

Several microorganisms are able to produce biosurfactants; however, the type of polymer produced is influenced by the origin of the microbe. Bacillus strains produce different surfactants with different surface-active properties.
B. pumilus is reported as lipoprotein type surfactin family producer (Peypoux et al. 1999; Banat et al. 2000). This polymer is particularly interesting because it has a high surface activity and can be used in large industrial sectors.

When compared with synthetic surfactants, the biosurfactants have more acceptability and exhibit some advantages such as biodegradability, low toxicity, better compatibility with the environment, high selectivity, effectiveness at extreme temperatures, $\mathrm{pH}$ and salinity and the possibility of production using alternative substrates (Desai and Banat 1997; Rosenberg and Ron 1999). These advantages make them as the target molecules in relation to environmental management issues and industrial applications.

*Author for correspondence: roberto_viana@yahoo.com 
The production from renewable substrates could reduce one of the limiting factors: the production costs, which is associated with inefficient methods for product recovery and use of expensive medium in the processing (Santos et al. 2010). However, the success of biosurfactant production depends on the use of a residue with appropriate balance of nutrients that permit the growth of microorganism and the synthesis of the interest product (Makkar and Cameotra 1997). Moreover, the type and properties of the final molecule produced depend on the composition of the culture medium (Besson and Michel 1992; Calvo et al. 2009).

Alternative substrates which are environmental problems are being seen as attractive sources for the biotechnological processes. The oily substrates have been proved to be good renewable carbon sources for the production of biosurfactants (Shah et al. 2007; Haba et al. 2000; Sarubbo et al. 1999; Sarubbo et al. 2007; Bednarski et al. 2004). In this context, the vinasse, a byproduct of ethanol production, could also be an attractive substrate and its use could open an avenue for the production of biosurfactants. Thus, the aims of this study was to use vinasse and waste frying oil as alternative carbon sources for the production of biosurfactant by Bacillus pumilus and to analyze the physicochemical properties of the polymer produced.

\section{MATERIALS AND METHODS}

\section{Microorganisms}

Bacillus pumilus (CCT 2487) was obtained from the Tropical Foundation of Research and Technology "André Tosello" (Campinas/SP) and was presevred kept aerobically in inclined tubes of nutrient agar (Difco) at $4{ }^{\circ} \mathrm{C}$.

\section{Substrate preparation}

The insoluble solids from both the substrates were removed by filtration on cellulose fibers. The $\mathrm{pH}$ was adjusted to 7.0 and sterilized at $121{ }^{\circ} \mathrm{C}$ for 15 minutes.

\section{Cultivation conditions}

For biosurfactant production, a medium rich in minerals salts proposed by Bicca et al. (1999), was used. It contained $(\mathrm{g} / \mathrm{l}): \mathrm{NaNO}_{3} 7.0 ; \mathrm{K}_{2} \mathrm{HPO}_{4}$ 1.0; $\mathrm{KH}_{2} \mathrm{PO}_{4} 0.5 ; \mathrm{KCl} 0.10 ; \mathrm{MgSO}_{4} 7 \mathrm{H}_{2} \mathrm{O} 0.50 ; \mathrm{CaCl}_{2}$, $0.01 ; \mathrm{FeSO}_{4} .7 \mathrm{H}_{2} \mathrm{O} ; 0.01$ yeast extract 0.1 and diesel $1 \%(\mathrm{v} / \mathrm{v})$. The $\mathrm{pH}$ was adjusted to 7.0. The production medium consisted the medium as above supplemented with 1 to $5 \%$ total solids of vinasse and waste frying oil, respectively, adjusted by refractometry.

\section{Biosurfactant production}

The bacterial strain was streaked on a nutrient agar slant and incubated at $30^{\circ} \mathrm{C}$ for $24 \mathrm{~h}$. The bacterial suspension (3\%) was inoculated in the $50 \mathrm{ml}$ the production medium contained in a $250 \mathrm{ml}$ Erlenmeyer flask and incubated in a rotary shaker (Marconi, model MA 830) at $200 \mathrm{rpm}$ and $30{ }^{\circ} \mathrm{C}$ for $24 \mathrm{~h}$. The inoculum amount used was equivalent to achieve the absorbance $0.5\left(\mathrm{OD}_{620}\right.$ $\left.{ }_{\mathrm{nm}}\right)$. The biosurfactant production was evaluated at 24, 48, 72 and $96 \mathrm{~h}$. After each fermentation period, the culture broth was centrifuged at $7077 \mathrm{~g}$ at $4{ }^{\circ} \mathrm{C}$ for $15 \mathrm{~min}$ (Jouan model GR 2022). All the experiments were conducted in triplicate.

\section{Analytical methods \\ Biomass}

The cells separated by centrifugation were suspended in $50 \mathrm{ml}$ of distilled water and microbial growth was determined in spectrophotometer at $620 \mathrm{~nm}$ (Bel photonics, model SP 1105). The absorbance values were correlated with the cell biomass by calibration of the absorbance curve versus cell mass in triplicate.

\section{Surface tension measurement}

The surface tension was determined directly in a tensiometer (Leconde du Nouy) at $25^{\circ} \mathrm{C}$ in $10 \mathrm{ml}$ of cell-free supernatants obtained by centrifugation.

\section{Emulsification index $\left(\mathbf{E}_{24}\right)$}

The emulsification index was determined by adding $2.0 \mathrm{ml}$ of toluene to $3.5 \mathrm{ml}$ of cell-free broth in a graduated tube and vortexed at high speed for $2 \mathrm{~min}$. The emulsion was analyzed after $24 \mathrm{~h}$. The emulsification index $\left(\mathrm{E}_{24}\right)$ was calculated by dividing the measured height of emulsion layer by the mixture's total height and multiplying by 100 (Iqbal et al. 1995).

\section{Critical micelle concentration determination}

It was determined by measuring the surface tension of dilutions of the cell-free broth in distilled water. The CMC was represented by a graph of surface tension versus concentration of the biosurfactant. 


\section{Biosurfactant isolation}

After 24, 48, 72 and $96 \mathrm{~h}$, the cell-free culture broth was precipitated with absolute ethanol (1:3 $\mathrm{v} / \mathrm{v}$ ), maintained for $24 \mathrm{~h}$ at $4{ }^{\circ} \mathrm{C}$, decanted and dried at $55^{\circ} \mathrm{C}$ until constant weight.

\section{RESULTS AND DISCUSSION}

B. pumilus was able to grow and produce biosurfactant in the medium containing alternative substrates as carbon source and energy. The $\mathrm{pH}$ variation analyzed after each period of fermentation was different between the substrates and their concentrations. There was wide variation in relation to the initial $\mathrm{pH} 7.0$ when the waste frying oil substrate was use; however, when vinasse was used, there was an increase in the $\mathrm{pH}$ to around 9.0. This increase could be associated directly with the cell growth due to the secretion of some substances in the medium or by the liberation of compounds due to cell lysis.

Vinasse and waste frying oil demonstrated different capacities to reduce the surface tension depending up on the concentration and fermentation times tested (Tables 1 and 2). The best result of reduction in surface tension was 45 $\mathrm{mN} / \mathrm{m}$ for both the substrates tested, $38.2 \%$ in relation to the surface tension of the water $(72.8$ $\mathrm{mN} / \mathrm{m}$ ). Bento et al. (2003) obtained $49.5 \mathrm{mN} / \mathrm{m}$ surface tension in a culture medium containing minerals salts and yeast extract for biosurfactant production by $B$. pumilus. Using waste frying oil, Lima et al. (2007) found a reduction of surface tension up to $33.9 \mathrm{mN} / \mathrm{m}$ by Pseudomonas sp. Santos et al. (2010) used a culture medium based on soybean oil and found that, $P$. fluorescens reduced the surface tension up to $49.5 \mathrm{mN} / \mathrm{m}$ (Santos et al. 2010).

Table 1 - Effect of different vinasse concentrations (\%) on surface activity of biosurfactant produced by Bacillus pumilus at $24,48,72$ and 96 hours of fermentation at $30^{\circ} \mathrm{C}, 200 \mathrm{rpm}$.

\begin{tabular}{|c|c|c|c|c|}
\hline \multirow{2}{*}{$\begin{array}{c}\text { Vinasse } \\
\text { Concentration }(\%)\end{array}$} & \multicolumn{4}{|c|}{$\begin{array}{c}\text { Surface tension (mN/m) } \\
\text { Fermentation time (hours) }\end{array}$} \\
\hline & 24 & 48 & 72 & 96 \\
\hline 1 & $49 \pm 0.0$ & $50 \pm 1.0$ & $51 \pm 0.3$ & $51 \pm 0.5$ \\
\hline 2 & $47 \pm 0.5$ & $49 \pm 0.3$ & $50 \pm 0.2$ & $49.5 \pm 0.5$ \\
\hline 3 & $46 \pm 0.5$ & $47 \pm 0.0$ & $47.5 \pm 0.0$ & $50 \pm 0.0$ \\
\hline 4 & $45 \pm 0.5$ & $46 \pm 0.0$ & $49 \pm 0.3$ & $51 \pm 0.5$ \\
\hline 5 & $46 \pm 0.3$ & $45.5 \pm 0.0$ & $46.5 \pm 0.0$ & $49.5 \pm 0.0$ \\
\hline
\end{tabular}

*Data are means \pm standard deviations of three independent experiments.

Table 2 - Effect of different waste frying oil concentrations (\%) on surface activity of biosurfactant produced by Bacillus pumilus at $24,48,72$ and 96 hours of fermentation at $30^{\circ} \mathrm{C}, 200 \mathrm{rpm}$.

\begin{tabular}{|c|c|c|c|c|}
\hline \multirow{2}{*}{$\begin{array}{l}\text { Waste Frying Oil } \\
\text { Concentration }(\%)\end{array}$} & \multicolumn{4}{|c|}{$\begin{array}{l}\text { Surface tension (mN/m) } \\
\text { Fermentation time (hours) }\end{array}$} \\
\hline & 24 & 48 & 72 & 96 \\
\hline 1 & $48 \pm 1.0$ & $47.5 \pm 1.0$ & $45.5 \pm 0.3$ & $46.5 \pm 0.0$ \\
\hline 2 & $45 \pm 0.5$ & $46 \pm 0.3$ & $46.5 \pm 0.5$ & $47 \pm 0.5$ \\
\hline 3 & $49 \pm 0.5$ & $49 \pm 0.7$ & $49 \pm 0.0$ & $47.5 \pm 0.0$ \\
\hline 4 & $50 \pm 0.7$ & $46 \pm 0.0$ & $50.5 \pm 0.0$ & $47 \pm 0.5$ \\
\hline 5 & $46 \pm 0.0$ & $45 \pm 0.0$ & $49 \pm 0.0$ & $45 \pm 0.0$ \\
\hline
\end{tabular}

*Data are means \pm standard deviations of three independent experiments.

According to Figures 1 and 2, the biosurfactant production was not directly associated with the cell growth for both the substrates. This could have occurred by the influence of different substrate concentrations, $\mathrm{pH}$ and components of the medium that might have resulted in an microbial defense mechanism inhibiting or increasing the biosurfactant concentration. Similar result was observed by Nitschke and Pastore (2006) using B. subtilis and cassava wastewater as carbon source and by Sobrinho et al. (2008) using Candida sphaerica for biosurfactant production. However, the present results suggested that the microbial growth had a direct relationship with the 
decrease of the surface tension; the same suggestion was made in a study with $B$. pumilus isolated from oil contaminated soil (Calvo et al. 2004).

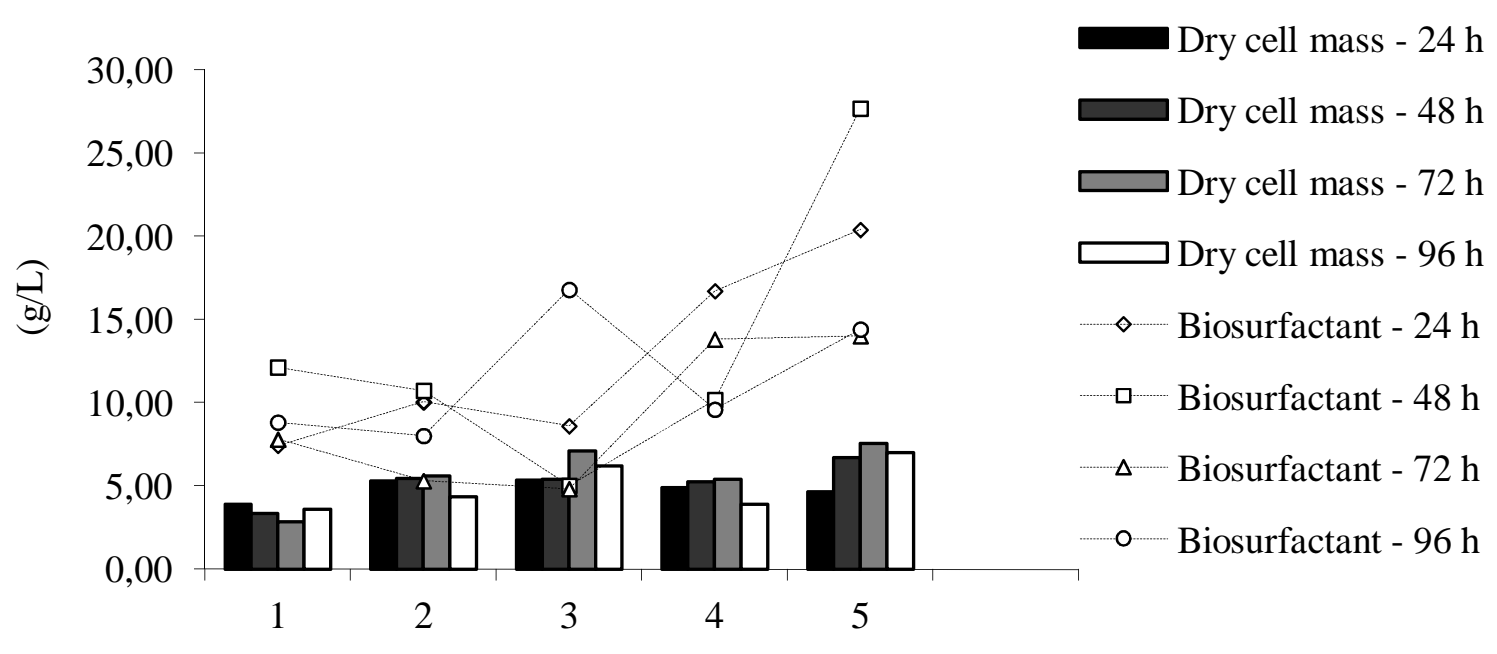

Vinasse Concentration (\%)

Figure 1 - Relation between biosurfactant production and dry cell mass during fermentation periods 24, 48, 72 and 96 hours in different vinasse concentrations by Bacillus pumilus incubated at $30^{\circ} \mathrm{C}$ and $200 \mathrm{rpm}$.

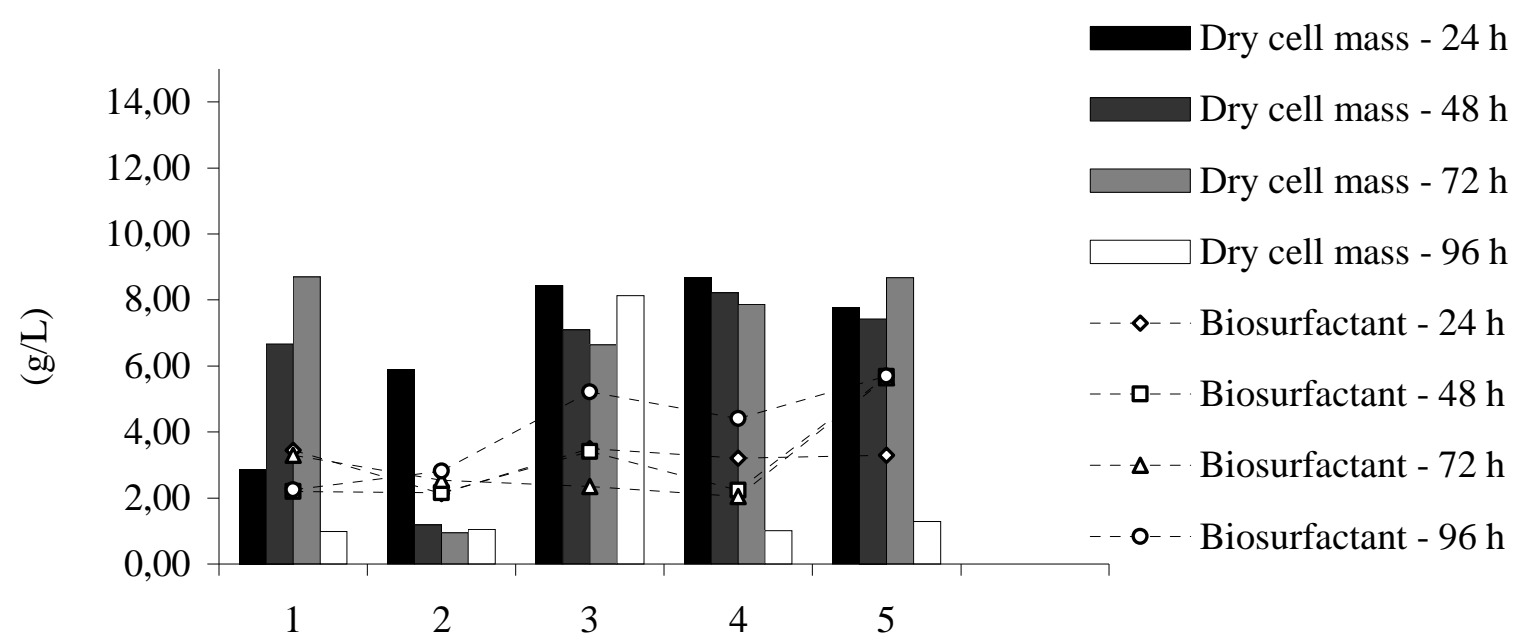

Waste Frying Oil Concentration (\%)

Figure 2 - Relation between biosurfactant production and dry cell mass during fermentation periods 24, 48, 72 and 96 hours in different waste frying oil concentrations by Bacillus pumilus incubated at $30{ }^{\circ} \mathrm{C}$ and $200 \mathrm{rpm}$.

In the present work, the microorganism behaved differently in each condition tested, which explained the importance of quantifying the production and to check the polymer properties 
produced at each substrate concentration in different fermentation periods. Figure 1 showed that the highest crude biosurfactant production using vinasse substrate occurred at 5\% after 24 and $48 \mathrm{~h}$ of fermentation, 20.4 and $27.7 \mathrm{~g} / \mathrm{l}$, respectively. Using waste frying oil, the highest production was at 5 and $3 \%$ after $96 \mathrm{~h}$ of fermentation, giving 5.7 and $5.21 \mathrm{~g} / \mathrm{l}$, respectively (Fig. 2). This result was better than the results observed by Haba et al. (2000) who using 2 and $4 \%$ of waste frying oil found $1.4 \mathrm{~g} / \mathrm{l}$ biosurfactant production by Pseudomonas sp.

The $\mathrm{E}_{24}$ of the cell-free broth did not show emulsion with toluene, probably due to the production of secondary metabolites, which could interfere with emulsion formation and adsorption of biosurfactant molecules at the hydrocarbonwater interface (Bonilla et al. 2005). However, previous studies have been reported $\mathrm{E}_{24}$ of 25.83 and $33.75 \%$ of the biosurfactant produced by $B$. pumilus using sucrose and molasses as carbon source, respectively (Oliveira 2010). This showed that the polymer properties produced were affected by the substrate used. The CMC is an index used to evaluate the surface-active activity that is the minimum biosurfactant concentration needed to achieve the lowest values of surface tension, from which the formation of micellar aggregates begins (Ron and Rosenberg 2001; Becher 1965).

The present study found the CMCs of 200 and $1500 \mathrm{mg} / \mathrm{l}$ in the supernatants of the waste frying oil and vinasse substrates, respectively. According to Mulligan (2005), the effectiveness of a biosurfactant is measured by the low values of the critical micelle concentration. Therefore, the biosurfactant produced by $B$. pumilus proved to be efficient with both carbon sources tested. These results were lower when compared with sodium dodecyl sulfate (SDS), synthetic surfactant commonly used in many industrial sectors, which has a CMC of $2100 \mathrm{mg} / \mathrm{l}$ (Chen et al. 2006).

\section{CONCLUSIONS}

The vinasse and waste frying oil appeared to be good alternative sources to promote microbial growth and biosynthesis of biosurfactant by $B$. pumilus. The polymer produced had interesting surface-active properties. The substrates used could reduce the biosurfactant production cost and make it more economically competitive, besides reducing the pollution resulting from their disposal to the environment.

\section{ACKNOWLEDGMENTS}

The authors thank the Coordination for the Improvement of Higher Education Personnel (CAPES) for financial support.

\section{REFERENCES}

Banat IM, Makkar RS, Cameotra SS. Potential commercial applications of microbial surfactants. Appl Microbiol Biotechnol. 2000; 53(5): 495-508.

Becher P. Emulsions, theory and practice. second edition. New York: Reinhold Publishing; 1965.

Bednarski W, Adamczak M, Tomasi, J, Plaszczik M. Application of oil refinery waste in the biosynthesis of glycolipids by yeast. Bioresour Technol. 2004; 95(1): 15-18.

Benincasa M, Contiero J, Manresa MA, Moraes IO. Rhamnolipid production by Pseudomonas aeruginosa LBI growing on soapstock as the sole carbon source. J Food Eng. 2002; 54(4): 283-288.

Bento FM, Camargo FAO, Okeke B, FrankenbergerJúnior WT. Bioremediation of soil contaminated by diesel oil. Braz J Microbiol. 2003; 34 suppl 1: 65-68.

Besson F, Michel G. Biosynthesis of iturin and surfactin by Bacillus subtilis: Evidence for amino acid activating enzymes. Biotechnol Lett. 1992; 14(11): 1013-1018.

Bicca FC, Fleck LC, Ayub MAZ. Production of biosurfactant by hydrocarbon degrading Rhodococcus ruber and Rhodococcus erythropolis. Rev Microbiol. 1999; 30(3): 231-236.

Bonilla M, Olivaro C, Corona M, Vazquez A, Soubes, M. Production and characterization of a new bioemulsifier from Pseudomonas putida ML2. J Appl Microbiol. 2005; 98(2): 456-463.

Calvo C, Toledo FL, González-Lopez J. Surfactant activity of a naphthalene degrading Bacillus pumilus strain isolated from oil sludge. J Biotechnol. 2004; 109(3): 255-262.

Calvo C, Manzanera M, Silva-Castro GA, Uad I, González-López J. Application of bioemulsifiers in soil oil bioremediation processes. Future prospects. Sci Total Environ. 2009; 407: 3634-3640.

Chen J, Wang XJ, Hu JD, Tao S. Effect of surfactants on biodegradation of PAHs by white-rot fungi. Environ Sci. 2006; 27(1): 154-159.

Desai JD, Banat IM. Microbial production of surfactants and their commercial potential. Microbiol Mol Biol Rev. 1997; 61: 47-64. 
Haba E, Espuny MJ, Busquets M, Manresa A. Screening and production of rhamnolipids by Pseudomonas aeruginosa 47T2 NCIB 40044 from waste frying oils. J Appl Microbiol. 2000; 88: 379387.

Iqbal S, Khalid ZM, Malik KA. Enhanced biodegradation and emulsification of crude oil and hyperproduction of biosurfactants by a gamma rayinduced mutant of Pseudomonas aeruginosa. Lett Appl Microbiol. 1995; 21(3): 176-179.

Lima CJB. Produção de biossurfactante por Pseudomonas aeruginosa empregando óleo de soja residual [Tese de doutorado]. Uberlândia, Minas Gerais, Brasil: Universidade Federal de Uberlândia; 2007.

Makkar RS, Cameotra SS. Utilization of molasses for biosurfactant production by two Bacillus strains at thermophilic conditions. J Am Oil Chem Soc. 1997; 74(7): 887-889.

Mulligan CN. Environmental applications for biosurfactants. Environ Pollut. 2005; 133(2): 183198.

Nitschke M, Pastore GM. Production and properties of a surfactant obtained from Bacillus subtilis grown on cassava wastewater. Bioresour Technol. 2006; 97(2): 336-341.

Oliveira JG. Produção de biossurfactante por Bacillus pumilus e avaliação da biorremediação de solo e água contaminados com óleo [Dissertação de Mestrado]. São José do Rio Preto, São Paulo, Brasil: Universidade Estadual Paulista; 2010.

Peypoux F, Bonmatin JM, Wallach J. Recent trends in the biochemistry of surfactin. Appl Microbiol Biotechnol. 1999; 51(5): 553-563.
Ron EZ, Rosenberg E. Natural roles of biosurfactants. Environ Microbiol. 2001; 3(4): 229-236.

Rosenberg E, Ron EZ. High- and low-molecular-mass microbial surfactants. Appl Microbiol Biotechnol. 1999; 52(2): 154-162.

Santos SC, Fernandez LG, Rossi-Alva JC, Roque MRA. Evaluation of substrates from renewableresources in biosurfactants production by Pseudomonas strains. African J Biotechnol. 2010; 9(35): 5704-5711.

Sarubbo LA, Porto AL, Campos-Takaki GM. The use of babassu oil as substrate to produce bioemulsifiers by Candida lipolytica. Can J Microbiol. 1999; 45: 423-426.

Sarubbo LA, Farias CBB, Takaki GMC. Co-utilization of canola oil and glucose on the production of a surfactant by Candida lipolytica. Cur Microbiol. 2007; 54: 68-73.

Shah V, Jurjevic M, Badia D. Utilization of restaurant waste oil as a precursor for sophorolipid production. Biotechnol Prog. 2007; 23: 512-515.

Sobrinho HBS, Rufino RD, Luna JM, Salgueiro AA, Campos-Takaki GM, Leite LFC, et al. Utilization of two agroindustrial by-products for the production of a surfactant by Candida sphaerica UCP0995. Process Biochem. 2008; 43: 912-917.

Yin H, Qiang J, Jia Y, Ye J, Peng H, Qin H, et al. Characteristics of biosurfactant produced by Pseudomonas aeruginosa S6 isolated from oilcontaining wastewater. Process Biochem. 2009; 44: 302-308 